\title{
ОСОБЛИВОСТІ РЕГУЛЮВАННЯ ФІНТЕХУ В ЄВРОПЕЙСЬКОМУ СОЮЗІ
}

Бухарін Г. О.

Стаття презентує дослідження еволюції законодавства Європейського Союзу щодо нормативно-правового регулювання ринку платежів як компоненти екосистеми галузі фінтеху. У статті проаналізовані процеси становлення та розвитку інфраструктури роздрібних платежів, ринку електронних платежів та введення принципів відкритого банкінгу - Open Banking - у Європейському Союзі, а також нормативно-правові акти, що їх регулюють. Наведені особливості імплементації законодавства про фінтех у Європейському Союзі та складнощі, що виникли у процесі. Як висновок, доведене велике значення чинного законодавства з регулювання платежів у Європейському Союзі для розвитку галузі фінтеху на всьому європейському просторі та за його межами з огляду на надання рівних можливостей на фінансовому ринку традиційним фінансовим установам та цифровим фінтех-команіям.

Ключові слова: фінтех, фінтех-індустрія, регулювання, ринок платежів, $Є$.

Статья представляет исследование эволюции законодательства Европейского Союза по нормативно-правовому регулированию рынка платежей как компоненты экосистемы отрасли финтеха. В статье проанализированы процессы становления и развития инфраструктуры розничных платежей, рынка электронных платежей и введение принципов открытого банкинга - Open Banking - в Европейском Союзе, а также нормативно-правовые акты, которые их регулируют. Приведены особенности имплементации законодательства о финтехе в Европейском Союзе и сложности, возникшие в процессе. Как вывод, доказано большое значение действующего законодательства по регулированию платежей в Европейском Союзе для развития отрасли финтеха на всем европейском пространстве и за его пределами с учетом предоставления равных возможностей на финансовом рынке традиционным финансовым учреждениям и цифровым финтех-команиям.

Ключевые слова: финтех, финтех-индустрия, регулирование, рынок платежей, $E C$.

Bukharin H. O. Peculiarities of fintex regulation in the European Union

The development of the fintech industry is inextricably linked with the concept of the payment market, in which it mainly develops and, accordingly, with the payment systems, which is one of the main directions of fintech industry.

The article presents a study of the evolution of EU legislation on legal regulation of the payment market as a component of the ecosystem of the fintech industry. The article analyzes the processes of formation and development of the infrastructure of retail payments, the electronic payment market and the introduction of the principles of Open Banking in the EU, as well as the regulatory legal acts that govern them. Peculiarities of implementation of fintech legislation in the EU and difficulties that have arisen in the process are given. As a conclusion, the great importance of the current legislation on regulating

(c) Бухарін Г. О., 2020 payments in the EU for the development of the fintech industry throughout the European space and beyond, taking into account the provision of equal opportunities in the financial market to traditional financial institutions and digital fintech companies, has been proved. Current legislation on fintech industry (PSD2 - in particular) in the EU obliges the banking sector to provide financial and private information about its customers to the information technology sector, which directly includes new financial market players whose legal status is enshrined by the EU current legal acts. This form of incorporation of the traditional banking sector with innovative fintech companies in the forms of payment initiation and financial information aggregation service providers also helps to allocate financial risks in terms of IT development by connecting new partners and reducing IT development costs within the bank by connecting third parties - providers.

Key words: fintech, fintech industry, regulation, payments market, EU.

Постановка проблеми та її актуальність. Розвиток галузі фінтеху нерозривно пов'язаний із поняттям ринку платежів, у рамках якого він головним чином розвивається та, відповідно, - із платіжними системами, що $\epsilon$ одним із головних напрямів фінтеху. В Європейському Союзі (далі - ЄС) нині регулювання правовідносин, пов'язаних із платежами, відбувається, відповідно до Директиви PSD2 - Payment Services Directive 2015/2366 Директиви ЄС «Про платіжні послуги на внутрішньому ринку», яка вимагає від операторів платіжних сервісів прозорої діяльності та захисту споживачів, сприяє інноваційному розвитку платіжного ринку.

Директива ухвалена у 2015 р. та передбачала термін імплементації у 2 роки. Крім того, згідно із правилами покрокового набрання чинності, передбаченими нормативно-правовим актом, 14 вересня 2019 р. завершився перехідний етап на нові деталізовані технічні стандарти та вимоги щодо посиленої аутентифікації користувачів, передбачені Директивою. До цього моменту банки і провайдери платіжних послуг ЄС повинні були узгодити юридичну і технічну частину з вимогами положень Директиви.

3 ухваленням Директиви PSD2 в ЄC пов'язують початок ери відкритого банкінгу - Open Banking, що внесло значні корективи в діяльність усього фінансового сектора країн Європи та надало нового імпульсу для динамічного розвитку галузі фінтеху. Отже, з метою якісного аналізу особливостей регулювання фінтеху в ЄС доцільним уважається проаналізувати еволюцію нормативно-правового регулювання ринку платежів (зокрема, електронних) у ЄС.

Аналіз останніх досліджень і публікацій. Питання розвитку фінансових технологій та їх нормативно-правового регулювання $\epsilon$ об'єктом дослідження багатьох вітчизняних та закордонних учених і практиків, серед яких: Л. Дудинець [2], Н. Омельчук, [4], Н. Пантєлєєва [5], С. Паперник та О. Молотай [6], М. Пожида- 
єва [7], Г. Поченчук [8], В. Вайпан, Є. Губін та М. Єгорова [1], В. Загойті [3], А. Діденко [9], П. Гупта [13] Ф. Годіно [12], М. Маккеффрі й А. Шифф [14], Ч. Тейлор, К. Уілсон, Е. Холтінен, А. Морозова [15] та інші. Проте динамічний розвиток галузі фінтеху створює нові виклики процесам нормотворчості й імплементації нормативно-правових норм, а досвід країн $€ C$ із нормативно-правового регулювання галузі фінтеху $\epsilon$ недостатньо дослідженим з огляду на доцільність його використання у створенні вітчизняної законодавчої бази з регулювання фінтеху в Україні.

Мета статті - проаналізувати еволюцію законодавства ЄС про ринок платежів та платіжні системи, дослідити питання його імплементації у країнах-членах.

Виклад основного матеріалу. Як відомо, у 2007 р., згідно з Директивою про платіжні послуги (Перша платіжна директива - PSD1 - 2007/64/EC), у ЄС було сформовано Єдиний європейський платіжний простір для транзакцій в євро (Single Euro Payments Area - SEPA). Директива закріпила права і зобов'язання всіх користувачів платіжних послуг (споживачі, суб'єкти господарювання, підприємств, установ та організацій) з метою забезпечення доступної можливості, підвищення ефективності та надійності міжнародних платежів у $€ C$, зокрема кредитних переказів, прямих дебетових платежів і платежів за банківськими картками.

Отже, до компонентів сфери діяльності Єдиного європейського платіжного простору, сформованого у 2007 р., можна віднести [4]:

1. Платіжні доручення: згідно 3 положеннями Директиви PSD1, введено нові правила, що встановили порядок використання міжнародного номера банківського рахунку (IBAN) та ідентифікаційного коду банку (BIC); визначені правила здійснення безготівкових грошових переказів банками, які приєдналися до системи SEPA (починаючи із 28 січня 2008 р.); визначені відповідні умови виконання платежів, умови відправлення, отримання та відхилення платежів, права й обов'язки учасників, правові основи тощо.

2. Грошові перекази Софт (прямий дебет): Директива PSD1 закріпила можливість здійснення автоматичної оплати рахунків у всіх державах-членах $\in C$ для клієнтів банків, які приєдналися до системи SEPA (починаючи з 2 листопада 2009 року). У свою чергу, одержувачі автоматичної оплати рахунків отримали можливість накопичувати на одному рахунку платежі автоматичної оплати від всіх клієнтів, які роблять розрахунки за участю банків у межах Європейського Союзу, Норвегії, Швейцарії, Ісландії, Ліхтенштейну і Монако.

3. Банківські карти: саме Директива PSD1 закріпила можливість користуватися всіма випущеними в державах-членах $\in C$ розрахунковими картами в кожній із країн-учасниць $Є C$, згідно з нормами SEPA (починаючи із 2008 р.). Під користуванням розрахунковими картами мається на увазі емітація розрахункових карток із чіпами, згідно з EMV-стандартом, усіма банками країн ЄС, використання цих карток для розрахункових операцій і отримання готівки в банкоматах у всіх країнах-членах.

Отже, до 2015 р. в ЄС було досягнуто значного прогресу в інтеграції роздрібних платежів у Союзі, зокрема в контексті актів Союзу щодо платежів, а саме:

1. Директива Європейського парламенту та Ради 2007/64/€C (PSD1) встановила загальні правила щодо прозорості умов і вимог до інформації щодо платіжних послуг, а також відповідних прав та обов'язків користувачів та постачальників платіжних послуг щодо їх надання на постійній основі.

Як показала практика розвитку фінансового ринку в ЄC, обмежене коло суб'єктів надання платіжних послуг виявилося іï недоліком, що було переглянуто в наступних правових актах. Директивою було визначено лише шість категорій постачальників платіжних послуг:

кредитні установи у значенні статті 4 (1) (а) Директиви 2006/48/€С;

установи - емітенти електронних грошей у значенні ст. 1 (3) (а) Директиви 2000/46/ЄС;

поштові відділення або відділення зв'язку, які відповідно до національного законодавства мають право надавати платіжні послуги;

платіжні установи у значенні Директиви (2007/64/ ЄC - PSD1) - юридичні особи, яким надано дозвіл, відповідно до ст. 10 Директиви, на надання та здійснення платіжних послуг на всій території Співтовариства;

Європейський центральний банк та національні центральні банки, коли вони не виконують функції органу валютно-фінансового управління чи інших державних органів;

держави-члени або їхні регіональні чи місцеві органи влади, коли вони не діють як державні органи.

Під платіжними установами у значенні Директиви (2007/64/€С - PSD1), відповідно до ст. 10, розуміються такі, які отримали відповідний дозвіл від країни-члена $€ С$ на основі поданої заявки, інформація та докази в якій відповідають усім вимогам, передбаченим ст. 5 Директиви, та пройшли загальне оцінювання компетентними органами після перевірки заявки та, за необхідності, консультації компетентних органів із Національним центральним банком або іншими відповідними державними органами з отриманням сприятливої оцінки.

У ст. 5 Директиви (2007/64/€C - PSD1) визначено детальних перелік зобов'язань для перспективних постачальників платіжних послуг, які мають надати компетентним органам таку інформацію:

програму операцій, яка конкретизує, зокрема, передбачений вид платіжних послуг;

бізнес-план, що включає розрахунок прогнозного бюджету на перші три фінансові роки, який демонструє, що заявник може використовувати відповідні та пропорційні системи, ресурси та процедури для належної роботи;

докази того, що платіжна установа володіє початковим капіталом, передбаченим ст. 6 Директиви;

опис ужитих заходів щодо забезпечення грошових коштів користувачів платіжних послуг відповідно до ст. 9 Директиви;

опис механізмів управління та механізмів внутрішнього контролю заявника, включаючи адміністративні механізми, механізми управління ризиками та процедури обліку, який демонструє, що ці механізми управління, механізми контролю та процедури пропорційні, відповідні, надійні й адекватні;

опис механізмів внутрішнього контролю, які заявник встановив для виконання зобов'язань щодо відмивання грошей та фінансування тероризму відповідно до Директиви 2005/60/ЄС та Реґламенту (ЄС) № 1781/2006 Європейського парламенту та Ради від 
15 листопада 2006 р. «Про інформацію про платника, що супроводжує перерахування коштів»;

опис структурної організації заявника, зокрема

й інформації про те, у якому документі це зафіксовано; опис цільового використання агентів і філій, опис механізмів аутсорсингу та його участі в національній або міжнародній платіжній системі;

ідентифікацію юридичних осіб, які за статусом $\epsilon$ дочірніми філіями установи-зявника, прямо чи опосередковано, у значенні ст. 4 (11) Директиви, розмір їхніх фондів та докази їхньої придатності з урахуванням необхідності забезпечення надійного та розважливого управління платіжною установою;

ідентифікацію керівників та осіб, відповідальних за управління платіжною установою, та осіб, відповідальних за управління діяльністю платіжних послуг, а також докази того, що вони мають добру репутацію та володіють відповідними знаннями та досвідом здійснювати платіжні послуги, відповідно до визначених країною - членом платіжної установи вимог;

ідентифікацію обов'язкових аудиторів і аудиторських фірм, визначених Директивою 2006/43/ ЄС Європейського парламенту та Ради від 17 травня 2006 р. «Про обов'язковий аудит річних звітів та консолідованих звітів»;

правовий статус та статут заявника;

адресу головного офісу заявника.

Необхідно зауважити, що наведені вимоги залишаються чинними та закріплені в Директиві PSD2 «Про платіжні послуги на внутрішньому ринку».

2. Реґламент № 924/2009 Європейського парламенту та Ради «Про транскордонні платежі у Співтоваристві» та скасування попереднього Реґламенту № 2560/2001 «Про транскордонні платежі в євро», за результатами якого Європейською комісією було зафіксовано практичні проблеми стосовно порушення процедур внутрішнього ринку платежів, викликаного різними зобов'язаннями статистичної звітності через відсутність визначених національних компетентних органів, відсутність позасудових органів із питань відшкодування збитків та непокриття правовідносин, що виникають у зв'язку із прямими дебітами, ухвалений із метою належного функціонування внутрішнього ринку та сприяння транскордонній торгівлі в межах Співтовариства.

Реґламент № 924/2009 ухвалений із метою заохочення європейської платіжної галузі докласти необхідних зусиль для створення інфраструктури для платежів на всій території Співтовариства, закріпив принцип рівності, згідно з яким плата за транскордонні платежі в євро визначена такою ж, як і за відповідні платежі в межах держави-члена. Це правило застосовується до транскордонних платежів у євро та у шведських кронах до 50000 євро, або їх еквіваленті.

3. Директива 2009/110/ЄС Європейського парламенту та Ради «Про заснування, здійснення та пруденційний нагляд за діяльністю установ-емітентів електронних грошей, про внесення змін до Директив 2005/60/ ЄC та 2006/48/ЄС та скасування Директиви 2000/46/ $\epsilon C$ ». Директива встановила правила здійснення діяльності з випуску електронних грошей, для якої держави-члени повинні були визнати такі категорії емітентів електронних грошей:

кредитні установи, визначені в п. 1 ст. 4 Директиви 2006/48/ЄС, включаючи їхні філії, якщо вони роз- ташовані в межах Співтовариства, і їхні головні офіси, що розташовані за межами Співтовариства;

установи-емітенти електронних грошей, визначені в п. 1 ст. 2 Директиви, включаючи, відповідно до ст. 8 Директиви та національного законодавства, їхні філії, розташовані в межах Співтовариства, і головні офіси за межами Співтовариства;

поштові відділення або відділення зв'язку, які відповідно до національного законодавства мають право емітувати електронні гроші;

Європейський центральний банк та національні центральні банки, коли вони не виконують функції органу валютно-фінансового управління чи інших державних органів;

держави-члени або їхні регіональні чи місцеві органи влади, що виконують їхні функції державних органів.

Директивою встановлені правила та вимоги для прийняття, створення та пруденційного нагляду за діяльністю установ-емітентів електронних грошей.

4. Реґламент № 260/2012 Європейського парламенту та Ради «Про встановлення технічних та ділових вимог щодо кредитних переказів та прямих дебетів в євро та внесення змін до Реґламенту (ЄС) № 924/2009». Реґламентом зазначена необхідність створення інтегрованого ринку електронних платежів в євро, без різниці між національними та транскордонними платежами, для належного функціонування внутрішнього ринку, представлений проєкт Єдиного європейського платіжного простору для транзакцій в євро (SEPA), спрямованого на загальносоюзний розвиток платіжних сервісів та заміну системи існуючих на той час національних платіжних послуг.

У результаті запровадження відкритих, загальних платіжних стандартів, правил та практик, а також за допомогою інтегрованої обробки платежів у межах SEPA було забезпечено надання безпечних, конкурентоспроможних, зручних для користувачів та надійних платіжних послуг в євро. Навіть більше, положення Реґламенту та подальше встановлення простору SEPA полегшило доступ для нових учасників фінансового ринку та процедуру розроблення нових фінансових продуктів та швидкого впровадження інновацій, пов'язаних із платежами, у всьому Союзі, що, у свою чергу, сприяло інтенсивному розвитку галузі фінтеху у країнах-членах $\in C$.

5. Директива 2011/83/ЄС Європейського парламенту та Ради, яка додатково доповнила законодавчу базу для платіжних послуг установленням конкретного ліміту на здатність роздрібних торговців доплачувати своїм клієнтам за користування певним засобом платежу.

Проте розвиток фінансових технологій, які до 2015 р. стали доступнішими широкому колу користувачів, а також швидкий перехід до цифрового банкінгу засвідчили необхідність суттєвого перегляду та внесення змін до положень нормативно-правових актів із регулювання системи платежів, проаналізованих вище.

Отже, з метою розвитку ринку електронних платежів і створення сприятливих умов для здійснення безпечних платежів, що пропонують більш широкі можливості для здійснення розрахунків, 15 листопада 2015 р. в $\in C$ ухвалено Директиву PSD2 (2015/2366/EU) «Про платіжні послуги на внутрішньому ринку», яка відкриває 


\section{Правове забезпечення адміністративної реформи}

ринок платіжних послуг для більшого кола учасників, підвищує конкуренцію та розширює можливості клієнтів фінансових установ.

У цьому контексті необхідно підкреслити, що Директива PSD2 не $\epsilon$ логічною послідовністю положень Директиви PSD1. Навпаки, вона обмежує можливості традиційних фінансових інститутів (насамперед банків), жорстко спрямовує розвиток фінансової галузі в єдиному напрямі. Директива регулює платіжні послуги, ключові права споживачів, принципи взаємодії учасників ринку і закладає основу для абсолютно нової фінансової системи відкритого банкінгу.

Директива PSD2 створює нову інституційну ієрархію на фінансовому ринку та вводить у регулятивне поле нові типи інститутів-фінансових посередників [10]:

постачальники послуг 3 ініціації платежів (Payment Initiation Service Provider), які надають інтерфейси для здійснення платежів і виступають посередниками між споживачем і власником джерела фондування. Такі сервіси отримують право списувати кошти з будь-якого рахунку в будь-якому фінансовому інституті без узгодження з останнім;

постачальники послуг 3 агрегації фінансової інформації (Account Information Service Providers), які за дорученням клієнта запитують у фінансових організацій інформацію про його рахунки і консолідують їі в одному місці. Цікавою з погляду нормативно-правового регулювання в цьому контексті $\epsilon$ дефініція поняття «доручення клієнтом», адже таке доручення на передачу інформації, за нормами Директиви PSD2, може бути включено в будь-яку загальну оферту, коли клієнт вимушений погодитися із цією нормою за користування раніше придбаними товарами та послугами за договором оферти, що містить відповідну згоду.

Надаючи вільний доступ до європейського ринку різним платіжним системам, Директива PSD2 надає можливість небанківським платіжним сервісам здійснювати грошові перекази не тільки через банки, а й за допомогою різних платіжних агентів, через мережу телекомунікацій та операторів систем інформаційних технологій. Усе це сприяє конкуренції та розвитку інновацій у сфері фінансових технологій, а також вільній реалізації клієнтом (користувачем, споживачем) свого права на вибір найбільш прийнятного платіжного сервісу, що загалом впливатиме на рівень конкурентоспроможності європейських банків і платіжних компаній у глобальній світовій мережі електронних платежів.

Згідно з Директивою PSD2, ï правове регулювання поширюється i на такі нові види платіжних послуг, як оформлення платіжних доручень та консолідація фінансової інформації. Так, п. 10 цієї Директиви запроваджується низка нових бізнес-моделей за участю зовнішніх операторів платіжних послуг і визначається їхній правовий статус. До цієї категорії операторів належать учасники платіжного ринку, які надають допомогу клієнтам щодо запуску процесу переказу коштів шляхом складання від їхного імені електронного платіжного доручення і негайно передають повідомлення про сформований грошовий переказ торгово-сервісному підприємству, що дає останньому змогу моментально зробити відвантаження товару або надати доступ до послуги, придбаної в мережі Інтернет. Щоб скористатись такою послугою, клієнтові потрібно мати лише платіжний рахунок, доступний через Інтернет. А послуга з консолідації фінансової інформації дає йому змогу бачити загальну інформацію про свій фінансовий стан, можливість консолідувати дані про залишки на поточних рахунках та вести облік витрат за різними категоріями, тобто допомагає у фінансовому плануванні [7, с. 43-48].

Навіть більше, Директива поширює повноваження фінансових посередників через уведення зобов'язань фінансових організацій надавати їм інформацію без укладення окремого договору, отримувати доступ до платіжного рахунку користувача (клієнта фінансової установи) та використовувати інформацію про наявність на ньому грошових коштів. Із цією метою в $\in C$ підготовлені єдині стандарти обміну даними з фінансовими посередниками, обов'язкові для застосування на всій території ЄС, створений загальноєвропейський реєстр організацій, які мають статус платіжних інститутів, а також їх агентів.

3 іншого боку, з метою захисту прав користувачів (клієнтів) фінансових установ Директива вводить обов'язок упровадження посиленої аутентифікації під час отримання онлайн-доступу до рахунку, передачі розпоряджень про переведення коштів в електронному вигляді (які повинні здійснюватися наступного після передачі розпорядження дня за загальними правилами або впродовж чотирьох днів в окремих випадках), а також у разі наявності ризиків шахрайства.

За ознакою розміру статутного капіталу Директива PSD2 класифікує суб' єктів надання фінансових послуг платіжних небанківських інститутів - за трьома категоріями:

системи з переказу коштів із розміром уставного капіталу у 20 тис. євро;

сервіси з ініціації платежів із розміром уставного капіталу у 50 тис. євро;

безпосередньо платіжні інститути із розміром уставного капіталу у 125 тис. євро.

Диференційовані вимоги щодо мінімального розміру власних коштів (капіталу) пред'являються й до учасників платіжного ринку також.

Пруденційні вимоги до платіжних інститутів залишилися переважно незмінними, порівняно з Директивою PSD1.

Щодо сфери застосування Директиви PSD2, то вона не поширюється на платіжні інструменти з обмеженим функціоналом - тобто такі, які використовуються тільки в деяких торгових точках або для придбання обмеженого набору товарів і послуг. Також під дію Директиви не потраплять платежі через комунікаційних операторів у розмірі до 50 євро або до 300 євро на місяць для придбання цифрового контенту, благодійних платежів і покупки електронних квитків. Ця норма може мати як позитивний, так і негативний ефект для впровадження та розвитку продуктів фінтех-індустрії на фінансовому ринку - залежно від обставин.

Сприятливою для становлення та розвитку платіжних інститутів як провайдерів фінтех-продуктів $\epsilon$ зафіксована Директивою норма про можливість звільнення цих установ державами-членами від пруденційного нагляду за умови, якщо їхній річний оборот не перевищує 3 млн євро.

Директива затверджує обов'язки користувача (клієнта), які були введені раніше Директивою PSD1, щодо несанкціонованих операцій у розмірі 150 євро. Водно- 
час відповідальність може бути знята за умови негарантування рівня достатньої безпеки платіжного інструменту (наприклад, відсутність подвійної аутентифікації під час онлайн-доступу до рахунків). Натомість клієнт несе відповідальність за неавторизовані операції, якщо вони вчинені внаслідок порушення правил використання платіжного інструменту.

У результаті аналізу процедури імплементації революційної з погляду забезпечення умов сталого розвитку системи відкритого банкінгу та галузі фінтеху загалом Директиви PSD2 у країнах-членах $€ C$ необхідно зазначити, що вона зіткнулася 3 певними складнощами в різних країнах ЄС. Насамперед це стосується технічних особливостей - неспроможності технічного забезпечення системи відкритого банкінгу програмним забезпеченням не через недостатність його кількості, а через ускладнення його реалізації, правової легалізації та комерціалізації. Отже, технічні стандарти, що лежать в основі Директиви 2015 р., було доопрацьовано лише у вересні 2019 р.

По-друге, значною перешкодою для процесу імплементації Директиви в національне законодавства держав-членів стала недовіра користувачів (клієнтів) до нововведених небанківських платіжних інститутів та їхнє небажання надавати небанківським установам доступ до своїх рахунків, включно з історією транзакцій та структурою витрат, а також свою приватну інформацію та фінансові дані. Так, з метою моніторингу ступеня лояльності клієнтів фінансових установ до перспективних платіжних (небанківських) інститутів у ЄС було проведено соціологічне опитування службою платежів Accenture, яке виявило, що дві третини споживачів фінансових послуг у ЄС не бажають ділитися своїми даними зі сторонніми постачальниками фінансових послуг i «у більшості довіряють фінансову інформацію виключно своєму банку» [11]. Як контрарґумент побоюванням клієнтів банків у ЄС, технічні спеціалісти наполягають на забезпеченні передбачених Директивою надійної системи ідентифікації користувачів та посиленого захисту інформації під час ії передачі третім особам - стороннім провайдерам.

Висновки. Проведене дослідження еволюції законодавства $€ C$ про ринок платежів та платіжні системи, а також питань його імплементації у країнах-членах доводить велике значення Директиви PSD2 для розвитку галузі фінтеху на всьому європейському просторі та за його межами. Адже Директива надає рівні можливості на фінансовому ринку традиційним фінансовим установам і амбітним цифровим фінтех-команіям та стартапам через уведення зобов'язання для фінансових установ (передусім банків) надавати доступ до даних, щодо яких вони мають статус розпорядника інформації стосовно своїх клієнтів, через АРІ (програмний інтерфейс), використовувати ці дані з метою створення нових продуктів і управління фінансами за умови згоди клієнта. Інакше кажучи, Директива зобов'язує банківський сектор надавати фінансову та приватну інформацію про своїх клієнтів сектору інформаційних технологій, до якого безпосередньо належать нові гравці фінансового ринку, чий правовий статус закріплений положеннями Директиви.

У результаті ухвалення Директиви PSD2 учасники фінансового ринку ЄС отримали очевидні переваги. Згідно з новим законодавством, платіжні інсти- тути - провайдери фінансових послуг отримали доступ до даних клієнтів банків (за умови відповідного ліцензування й оцінювання, описаного в цьому підрозділі вище) отже, і можливість значно розширити клієнтську базу та надавати більш якісні й ефективні фінансові послуги.

Традиційні банківські установи за консолідації з перспективними фінтех-стартапами набули можливості розробляти та впроваджувати інноваційні фінтех-технології та продукти до системи надання традиційних фінансових послуг. Крім того, оновленим нормативно-правовим регулюванням для них передбачена можливість надавати інформацію небанківським установам на платній основі, надаючи відповідні дані як послуги з підключення провайдерів (постачальників) фінансових послуг до банківських інтерфейсів. Така форма інкорпорації традиційного банківського сектора 3 інноваційними фінтех-компаніями в особі постачальників послуг з ініціації платежів і агрегації фінансової інформації також сприяє розподілу фінансових ризиків з погляду IT-розробки завдяки підключенню нових партнерів, зниженню витрат на IT-розробку всередині банку за допомогою підключення третіх осіб - провайдерів.

\section{Література}

1. Вайпан В., Губин Е., Егорова М. Правовое регулирование экономических отношений в современных условиях развития цифровой экономики. Москва : Юстицинформ, 2019. $376 \mathrm{c}$.

2. Дудинець Л. Розвиток фінансових технологій як фактор модернізації фінансової системи. Глобальні ma національні проблеми економіки. 2018. Вип. 22. С. 794-798.

3. Загойти В. Зарубежный опыт регулирования финансовых технологий. Journal of Economy and Business. 2018. Вып. 5. Ч. 1. С. 77-79.

4. Омельчук Н. SEPA на пороге Украины. PaySpace Magazine. 2014, URL: https://psm7.com/analytics/sepaverge-ukraine.html (дата звернення: 05.06.2020).

5. Пантєлєєва Н. Фінансові інновації в умовах цифровізації економіки: тенденції, виклики та загрози. Приазовський економічний вісник. 2017. Вип. 3 (03). С. 68-73. URL: http://pev.kpu.zp.ua/journals/2017/3_03_uk/17.pdf (дата звернення: 20.05.2020).

6. Паперник С., Молотай О. Огляд правових аспектів в галузі ФінТех в Україні. Evris.Law. URL: https: / / evris.law/uk/stattja-ogljad-pravovih-aspektiv-vgaluzi-finteh-v-ukraini/ (дата звернення: 26.05.2020).

7. Пожидаєва М. Значення законодавства ЄС для захисту прав користувачів платіжних систем в Україні. Європейські та міжнародні підходи до захисту прав людини : матеріали Регіональної науково-практичної конференції, 7 квітня 2017 р. С. 43-48.

8. Поченчук Г. Fintech у структурі фінансової системи. Глобальні та національні проблеми економіки. 2018. № 21. C. 49-55. URL: http://global-national.in.ua/ archive/21-2018/11.pdf (дата звернення: 22.05.2020).

9. Didenko A. Regulating FinTech: Lessons from Africa. SSRN Electronic Journal. 2018. URL: http://dx.doi.org/ 10.2139/ssrn.3135604 (дата звернення: 29.05.2020).

10. Directive (EU) 2015/2366 of the European Parliament and of the Council "On payment services in the internal market" of 25 November 2015. URL: https://eur-lex.europa.eu/legalcontent/EN/TXT/?uri=CELEX:32015L2366 (дата звернення: 28.05.2020).

11. Europe begins Open Banking era in subdued style. FinExtra. URL: https: //www.finextra.com/newsarticle/31526/ 


\section{Правове забезпечення адміністративної реформи}

europe-begins-open-banking-era-in-subdued-style звернення: 09.06.2020).

(дата

12. Gaudino B. The FinTech Ecosystem Between Legal Compliance and Social Dimension. The RegTech Book. 2019. URL: https://doi.org/10.1002/9781119362197.ch57 (дата звернення: 28.05.2020).

13. Gupta P. Chapter 25. Legal Implications of Fintech. Fintech: The New DNA of Financial Services. Berlin ; Boston : De Gruyter, 2018. P. 453-488. URL: https://doi.org/ 10.1515/9781547400904-025 (дата звернення: 29.05.2020).

14. McCaffrey M., Schiff A. Finclusion to Fintech: Fintech Product Development for Low-Income Markets. SSRN
Electronic Journal. 2017. URL: http://dx.doi.org/10.2139/ ssrn. 3034175 (дата звернення: 29.05.2020).

15. Institutional Arrangements for Fintech Regulation and Supervision / C. Taylor et al. FinTech Notes. 2020. № 19 (02). URL: https://doi.org/10.5089/9781513520308.063 (дата звернення: 30.05.2020).

Бухарін Г. О., аспірант кафедри адміністративного та господарського права Запорізького національного університету 